\title{
Development of Varroa jacobsoni in colonies of Apis mellifera capensis and Apis mellifera carnica
}

\author{
RFA Moritz *, D Mautz \\ Bayerische Landesanstalt für Bienenzucht, Burgbergstr. 70, 8520 Erlangen, FRG
}

(Received 8 March 1989; accepted 20 December 1989)

\begin{abstract}
Summary - Honey bee colonies (Apis mellifera carnica), infested with Varroa jacobsoni were dequeened and divided into 2 subunits. Each pair of subunits were requeened with an inseminated $A m$ capensis and $A m$ carnica queen. The development of the mite population was monitored by determining the number of mites in samples of brood, and worker bees, and the number of dead mites on the bottom board of the hive. The mite population showed a restricted development in $A \mathrm{~m} \mathrm{Ca}$ pensis colonies. Varroa mites were found at surprisingly low frequencies on adult worker bees of the Cape honeybee. A more efficient grooming activity, in combination with the short post-capping stage of the brood, may be the central factors for the restricted development of the mite population in $A \mathrm{~m}$ capensis.
\end{abstract}

Apis mellifera / Varroa jacobson / resistance / post-capping stage / field study

\section{INTRODUCTION}

The parasitic mite, Varroa jacobsoni has become one of the most dangerous pests for bee keeping worldwide. Many efforts for efficient control have been made in the past decade but most approaches used acaricides to treat the disease (Needham et al, 1988, Ritter, 1988a). This led to a control of Varroatosis but also to problems with residues in honey, wax and other bee products. Presently there is an increasing need for biological techniques in the control of $V$ jacobsoni.

A biotechnological method, the "trapping comb technique", has been suggested by Maul (1983) and Maul et al (1988). The queen is restricted to a single brood comb which "traps" the reproductive mites in the colony. After 3 brood cycles more than $90 \%$ of the mite population can be trapped and removed from the colony by this technique. Though the method is applicable to small scale bee keeping operations which mainly harvest spring honey flows, it seems less appropriate for the commercial honey producer who also works honey flows in the late season.

Another approach to deal with Varroatosis in the long run seems to be the development of resistant stock. There are repeated reports that European honeybees in South America do not suffer seriously from Varroa infestations (Ruttner et al, 1984; Engels et al, 1986). It is presently unclear as to how the bees in South America achieve Varroa control. Moritz and

* Correspondence and reprints. 
Hänel (1984) and Moritz (1985) showed a potential resistance to Varroatosis in the Cape honeybee, Apis mellifera capensis. The brood of the Cape honey bee, like other African races of honey bees (Fletcher, 1978), has a shorter post-capping stage than European races. On average, the adult $A m$ capensis worker emerges 9.7 days after sealing of the cell. Because the Varroa mite development takes at least $10 \mathrm{~d}$ to produce the first infective offspring (Ifantidis, 1983), Varroa reproduction is restricted in worker brood of the Cape honey bee. Only $21 \%$ of the mites can produce even 1 infective offspring, and the other $79 \%$ are unlikely to produce any viable offspring. Since the short post capping stage proved to be selectable (Moritz, 1985), a breeding scheme for this character might result in resistant stock. However, so far only small scale experiments in the laboratory or in cages have been performed. Empirical data is lacking on the development of Varroa populations in full-size managed colonies with a short post-capping stage. In this paper we report the results of such a field study.

\section{MATERIALS AND METHODS}

Five colonies of $A m$ carnica infested with $V$ jacobsoni were split in May, each split consisting of 2 brood frames, 1 empty, 1 pollen, and 1 honey comb. None of the colonies were equipped with drone combs, which prevented drone production throughout the experiment. The original queen was removed and each split was requeened with a carnica or a capensis queen which were inseminated with drones of the corresponding race. After 8 weeks we checked 50 workers of each of the splits and identified them biometrically as pure carnica and capensis, respectively (technique of Ruttner, 1988). Thus, the new queen had replaced the old worker force with her offspring. All colonies were placed in the same apiary to obtain equal environmental conditions for both capensis and car- nica colonies. Reinfestation of the test colonies by drifting bees could not be excluded but equally affected both test groups.

From July 5 we monitored the development of the mite populations in the experimental colonies, which by this time filled a regular 10 frame super with 4-5 brood combs. Dead mites were trapped on screened bottom boards. The dead mites were removed and counted at weekly intervals. Furthermore, bee and brood samples were analyzed to obtain a better estimate of the actual mite population. These samples were taken in 10 and 14 day intervals respectively to avoid unnecessary weakening of the colony. One hundred sealed brood cells with dark-eyed pupae were opened and the mites in the cells (both mothers and offspring) were counted. 50 bees from the brood nest area were collected and washed in alcohol to separate the mites from the bees. The experiment was discontinued at the end of the season in mid-October when the brood production in the colonies and development of the mite population decreased to unsubstantial numbers.

\section{RESULTS}

The experimental colonies developed slowly and had to be fed repeatedly because of a poor honeyflow. The brood nests varied between $2-3$ combs which, in any case was sufficient for unrestricted mite reproduction. Figure 1 shows the means and standard errors of the raw data. The standard errors are large because the degree of infestation in the original colonies was variable before they were divided. Nervertheless, a common pattern is apparent. There was a peak in the mite population in August which was observed in all 10 colonies, irrespective of their race. Though most of the differences are not statistically significant, the difference between the number of mites on carnica and capensis worker bees is significant for the period from August 9 to September 6 and in early October ( $t$-test, df $=8$; $\mathrm{t}$ ranges from $\mathrm{t}=$ 2.31 to $\mathrm{t}=.2 .91 ; P<0.05)$. 

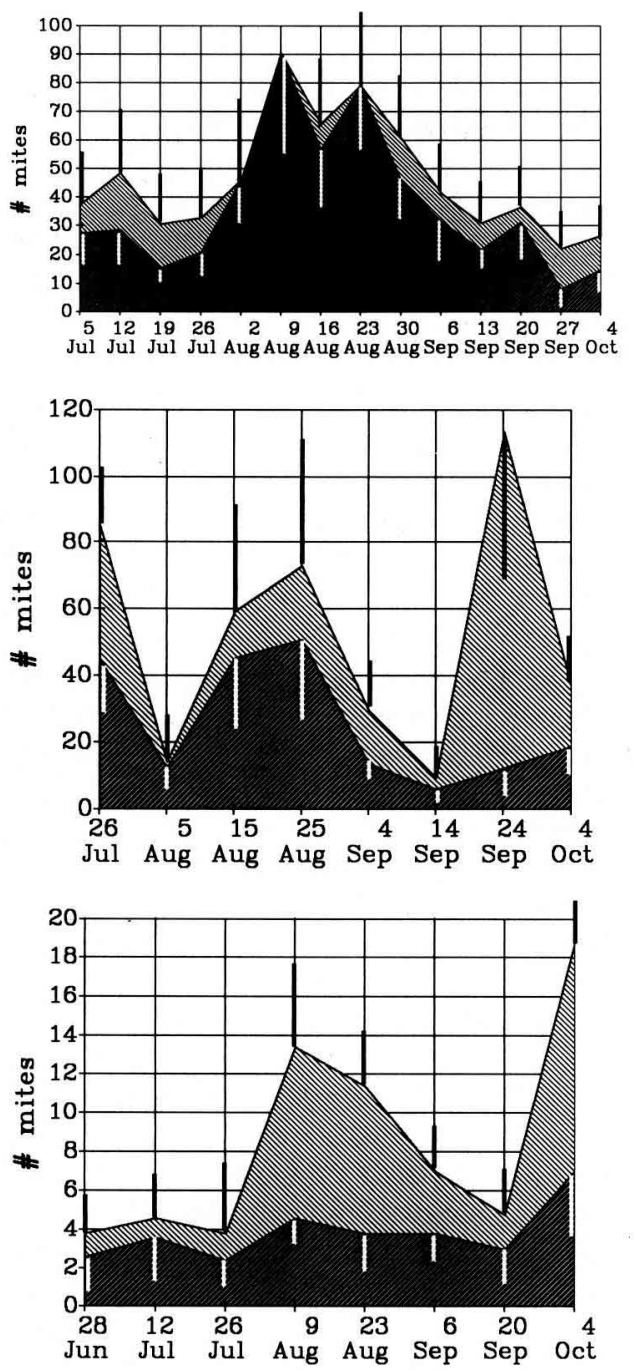

Fig. 1. Mean $\pm S E$ for the numbers of mites (\# mites) found on the bottom board (a), in samples of 50 brood cells (b), and on samples of 100 worker bees from the brood nest (c). The light shaded data with the black error bars indicates the data for Apis mellifera carnica and the dark shaded area with the white error bars reflects the Apis mellifera capensis data. The sampling dates are given on the $x$-axis.
Although we attempted to create colonies with similar degrees of infestation by using the split technique, there were some differences between the initial infestation rates of the colony pairs. Furthermore, the original colonies apparently had very different degrees of infestation. To compensate for those colony specific differences, we treated the data pairwise for each split. Thus, to document differences in the course of Varroa population development, we only compared the mite numbers on a given day for a given pair. The total number of mites found in a sample per split (capensis + carnica) was set equal $100 \%$ and only relative amounts of split pairs were used in the further analysis. Figure 2 shows the difference to the pooled data in figure 1 when the original "before split" variance of infestation is eliminated. The numbers of mites found in $A$ m capensis samples compared to $A m$ carnica samples decreases continuously throughout the season. Linear regression analysis of the relative numbers of mites on time (days) shows that the slopes are significantly smaller than zero for all 3 parameters tested (mites on bees: $\mathrm{b}=-0.42, P<0.01$; mites in brood: $b=-0.72, P<0.01$; mites on board: $\mathrm{b}=-0.26, P<0.05$ ).

\section{DISCUSSION}

The course of the Varroa infestation throughout the season was uncommon in our study. Usually the population reaches a maximum in October and does not decrease during September (Schulz, 1984; Ritter, 1988b). Unknown environmental conditions may have affected the mite population, since similar observations were made elsewhere in Germany at the same time of the year (Sakofski personal comm). 

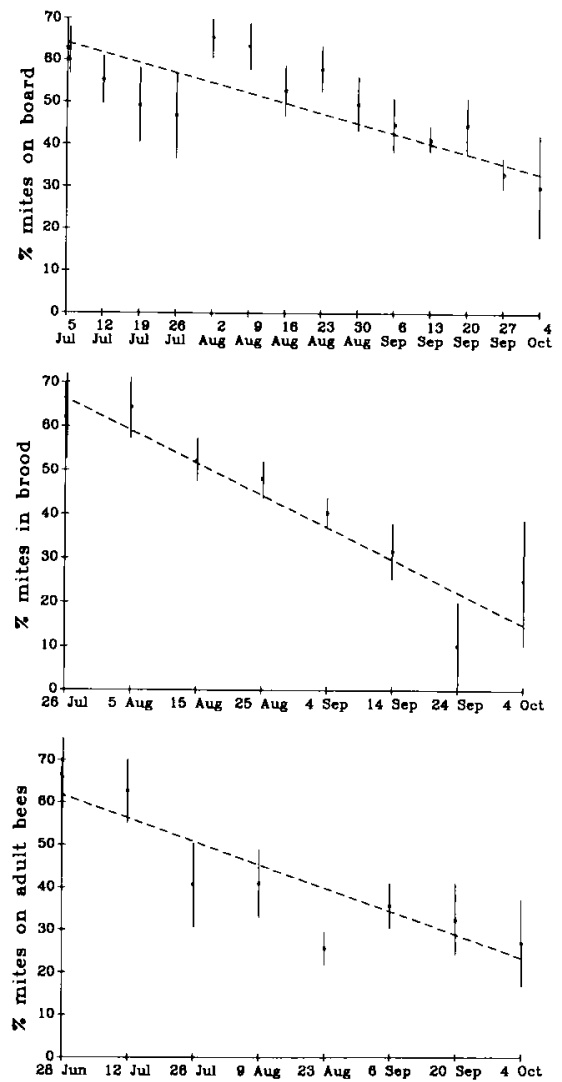

Fig. 2. Linear regression (dashed line) of the relative infestation of Apis mellifera capensis colonies (split pair data) on time based on; a) bottom board samples; b) brood samples; and c) worker bee samples. Data is given in means $\pm \mathrm{SE}$.

Although our methods of estimating degrees of infestation are not highly accurate (Fuchs, 1985), our results indicate that A $m$ capensis colonies are more tolerant to Varroa than $A m$ carnica colonies. The mite population is clearly restricted in its development in A m capensis. This could be due to the short post-capping stage (Moritz and Hänel, 1984). Camazine (1988) showed in a theoretical model based on the data of Schulz (1984) that because of the smaller replacement rate, Varroa mites in European honey bees should reach a population 5 times as large as in African honey bees in only 10 generations. We tested the colonies for 7 mite generations at the most and would not expect such dramatic differences in our data.

The October data for mites on adult worker bees and mites in brood suggest that the $A m$ carnica colonies are about 3 times as heavily infested as the $A m$ capensis colonies. This is close to Camazine's (1988) predictions based on a replacement rate for mites in European honey bees of $R=-1.8$ and of $R=-1.2$ for African honey bees.

Although the post-capping period is of central importance for the reproduction of $V$ jacobsoni, other parameters have also been shown to affect the mites. Peng (1988) recently showed that extensive grooming and allogrooming behaviour of $A$ cerana workers is highly efficient in eliminating mites from the colony. More than $99 \%$ of the mites could be removed by behavioural activities of the workers in $A$ cerana. Similar behaviour has been claimed for A m meda from Iran (Pourelmi, 1989). Our data are consistent with the notion that the workers of $A m$ capensis are also better equipped to remove mites from their body than carnica bees. The critical data are the number of mites on bees in August. Although the number of dead mites and the number of mites in the brood are very similar for $A m$ carnica and $A m$ capensis, the number of mites on the bees are significantly different. Regardless of the apparent population peak in August, the degree of infestation on live workers remains almost constant in $A m$ capensis colonies. Furthermore, although the infestation of the brood is lower, the number of dead mites per colony is almost equal in both $A m$ capensis and $A m$ carnica colo- 
nies. A plausible explanation would be, that Cape honey bees are more efficient in removing mites than Carniolan bees. It is a well-known feature of African bees to show a higher motor activity than European bees. They are less steady on the combs and react more quickly to disturbances (Fletcher, 1978; Ruttner, 1988). An increased grooming activity, similar to that observed in A cerana (Peng, 1988), would explain the large numbers of dead mites found on the bottom board of $A m$ capensis colonies, at a low infestation rate on adult workers.

Selection toward Varroatosis resistant or tolerant strains becomes a major issue in practical honey bee breeding (Koeniger and Fuchs, 1988; Kulincevic and Rinderer, 1988). Selection for a short post-capping stage may be a possible way to achieve resistance, particularly in the light of its high heritability (Moritz, 1985). Nevertheless, it also seems promising to pursue other selection aims, like increased grooming activity to achieve the final goal of Varroatosis resistant honey bees.

\section{ACKNOWLEDGMENTS}

We wish to thank the Deutsche Forschungsgemeinschaft for financial support (RFAM) for this study.

\section{Résumé - Développement de Varroa jacobsoni dans des colonies d'Apis} mellifica capensis et d'Apis mellifica carnica. On a orpheliné et divisé en deux 5 colonies d'abeilles carnioliennes (Apis mellifica carnica) atteintes de varroatose. Les premières moitiés ont reçu une reine Apis mellifica carnica inséminée artificiellement, les $2^{\mathrm{es}}$ moitiés une reine Apis mellifica capensis. Le développement de la population d'acariens a été estimé d'après les paramètres suivants : $A$, nombre d'aca- riens morts sur le plancher de la ruche (fig 1a), B, nombre d'acariens présents dans le couvain (fig $1 b$ ) et $C$, sur les ouvrières (fig 1c). La population d'acariens a eu un développement moindre dans les colonies d'A $m$ capensis que dans les colonies de A $m$ carnica. Les 3 paramètres testés, ( $A$, $B, C)$ ont montré que la population d'acariens se développait beaucoup plus dans les colonies d'A m carnica que dans les colonies d' $A m$ capensis (fig $2 a, 2 b$ et $2 c$ respectivement). Un comportement de toilette plus efficace combiné à une durée de développement du couvain d'ouvrières plus courte chez capensis pourrait expliquer cette différence. Malgré la présence d'un plus grand nombre d'acariens morts sur le plancher de la ruche (fig 1a), le degré de parasitisme des ouvrières du Cap est resté constamment faible (fig. 1c).

Apis mellifica / Varroa jacobsoni / résistance / stade operculé / étude sur terrain

Zusammenfassung - Entwicklung von Varroa jacobsoni in Völkern von Apis mellifera capensis und Apis mellifera carnica. Fünf Varroatose-infizierte Bienenvölker (Apis mellifera carnica) wurden entweiselt und zweigeteilt. Die eine Hälfte erhielt eine instrumentell besamte Apis mellifera carnica Königin, die andere Hälfte eine Apis mellifera capensis Königin. Der Befallsverlauf wurde anhand von Gemüllproben (Abb 1a), Brutproben (Abb 1b) und Bienenproben (Abb 1c) abgeschätzt. Die Entwicklung des Milbenbefalls erwies sich in den Völkern der Kap-Honigbiene wesentlich günstiger als bei der CarnicaBiene. Alle drei geprüften Parameter, Gemüll (Abb 2a), Brut (Abb 2b), Bienen (Abb 2c), zeigten, daß sich die Milbenpopulation in den $A m$ carnica Völkern stärker entwickelt als in den $A m$ capensis Völkern. Neben der verkürzten Ent- 
wicklungszeit der Kap-Arbeiterinnenbrut, könnte auch noch ein verstärktes Putzverhalten eine Rolle spielen. Trotz hoher Milbenzahlen im Gemüll (Abb 1a) war der Befall lebender Kap-Arbeiterinnen (Abb 1c) konstant gering.

\section{Apis mellifera / Varroa jacobsoni / Resistenz / Entwicklungszeit / Feld- studie}

\section{REFERENCES}

Camazine S (1988) Factors affecting the severity of Varroa jacobsoni infestations on European and African honey bees. In: Africanized Honeybees and Bee Mites. (Needham GR, Page RE, Delfinado Baker M, Bowman CE, eds) Ellis Horwood, Chichester, 444-451

Engels W, Goncalves LS, Steiner J., Buriolla AH, Carichio-Issa MR (1986) Varroa-Befall von Carnica-Völkern in Tropenklima. Apidologie 17, 203-216

Fletcher DJC (1978) The African bee, Apis mellifera andansonii, in Africa. Annu Rev Entomol 23, 151-171

Fuchs S (1985) Untersuchungen zur quantitativen Abschätzung des Befalls von Bienenvölkern mit Varroa jacobsoni Oud. und zur Verteilung der Parasiten im Bienenvolk. Apidologie 16, 343-368

Ifantidis $M$ (1983) Ontogenesis of the mite Varroa jacobsoni in worker and drone brood cells. J Apic Res 22, 200-206

Koeniger N, Fuchs S (1988) Control of Varroa jacobsoni Oud. in honey bee colonies containing sealed brood cells. Apidologie 19, 117-130

Kulinčević JM, Rinderer TE (1988) Breeding honey bees for resistance to Varroa jacobso$n i$ analysis of mite population dynamics. $I n$ : Africanized Honeybees and Bee Mites. (Needham GR, Page RE, Delfinado-Baker $M$, Bowman CE, eds) Ellis Horwood, Chichester, 434-443
Maul V (1983) Varroa-Elimination mittels Brutbeschränkung auf Bannwaben - Neue Ergebnisse zur Wirksamkeit des Verfahrens. Apidologie 14, 260-261

Maul V, Klepsch A, Assmann-Werthmüller U (1988) Das Bannwabenverfahren als Element imkerlicher Betriebsweise bei starkem Befall mit Varroa jacobsoni Oud. Apidologie $19,139-154$

Moritz RFA (1985) Heritability of the postcapping stage in Apis mellifera and its relation to varroatosis resistance. $J$ Hered $76,267-270$

Moritz RFA, Hänel H (1984) Restricted development of the parasitic mite Varroa jacobsoni Oud. in the Cape honey bee, Apis mellifera capensis Esch. $Z$ angew Entomol 97, 91-95

Needham GR, Page RE, Delfinado-Baker M, Bowman CE (1988) Africanized Honey Bees and Mites. Ellis Horwood, Chichester

Peng YS (1988) The resistance mechanism of the Asian honey bee Apis cerana to the mite Varroa jacobsoni. In: Africanized Honeybees and Bee Mites. (Needham GR, Page RE, Delfinado-Baker $M$, Bowman $C E$, ed) Ellis Horwood, Chichester, 426-429

Pourelmi MR (1989) Die mögliche Resistenz der Biene Apis mellifera meda gegenüber der Varroa-Milbe. Mitteil. Bienenbesamung 1, 1718

Ritter W (1988a) Medications registered in Western Europe for Varroatosis control. Apidologie 19, 113-116

Ritter W (1988b) Varroa jacobsoni in Europe, the tropics, and the subtropics. In: Africanized Honeybees and Bee Mites. (Needham GR, Page RE, Delfinado Baker M, Bowman CE, eds) Ellis Horwood, Chichester, 349-359

Ruttner $F$ (1988) Biogeography and Taxonomy of Honeybees. Springer, Berlin

Ruttner F., Marx H, Marx G (1984) Beobachtungen über eine mögliche Anpassung von Varroa jacobsoni an Apis mellifera L. in Uruguay. Apidologie 15, 43-62

Schulz A (1984) Reproduktion und Populationsentwicklung der parasitischen Milbe Varroa jacobsoni Oud. in Abhängigkeit vom Brutzyklus ihres Wirtes Apis mellifera L. Apidologie $15,401-420$ 